\title{
Politické spektrum v České republice
}

\author{
Český volič mezi pravicí a levicí \\ PAVEL ŠIMONÍK \\ STEM - Středisko empirických výzkumů, Praha \\ Political Spectrum in the Czech Republic \\ Czech Voter between Right and Left
}

\begin{abstract}
The essay tries to map three main areas important for the interpretation of results of parliamentary elections. (1) long-term distribution of citizens of the Czech Republic on the left-right political continuum; (2) competition for the position in the political center; (3) expectations and behaviour of center-oriented voters. The study is supported by empirical evidence assembled from large representative data files realized by STEM (The Center of Empirical Studies) during 1990-1996. These files were collected on the base of STEM's own projects (investigative series TRENDS and Elections) and/or international comparative surveys (Party System and Political Alignment). The quantitative analysis of above mentioned data shows that, in spite of new constellation of political forces, the distribution of Czech voters on the leftright political continuum remains stable. Globally, the right-center position continues to prevail; there is no striking growth of left-wing orientations. A swing to the right would have meant calling for a change of regime, but according to our data this is not happening. While the voting behaviour of both left and right oriented population is constant, the center-oriented voters changed their preferences in favour of the Social Democratic Party. Moreover, the center-oriented voters represent a very vague voting potential. Thus, their identification with a certain political stream or subject is rather weak. Today, center-oriented voters support the nature of democratical political system developed after November 1989. At the same time, however, voters express dissatisfaction with the practical policy in certain areas (i.e., education, health care system, security). Thus, only parties offering a solution of the daily-life problems, not parties questioning the legitimacy of democratic system, will have a chance to gain support of center-oriented voters.
\end{abstract}

Sociologický časopis, 1996, Vol. 32 (No. 4: 457-469)

\section{1. Úvodem}

Výsledek letošních parlamentních voleb vyvolal řadu laických i odborných diskusí na téma směřování českého voliče, politický střed, krystalizace politické scény apod. Diskutuje se o prohloubení politické polarizace společnosti po volbách, o smysluplnosti tradičního rozřazování stran a jejich voličů na pravolevém kontinuu. Z hlediska sociologických dat však volbami nastolený poměr politických sil nepředstavuje nic nečekaného a překvapivého. Výsledky výzkumů STEM již od konce roku 1994 hovoří o křehké společenské rovnováze, o rostoucí nespokojenosti veřejnosti s formou realizace politiky, která však neznamená odmítnutí polistopadového vývoje. Současný režim má podporu především v rovině obecných hodnot, zatímco v rovině každodenní reality jsou nálady dosti kritické.

*) Veškerou korespondenci posílejte na adresu: Pavel Šimoník, STEM, s.r.o., Jilská 1, 11000 Praha 1, tel. (02) 242209 79, 1. 331, 226. 
Lidé souhlasí s obecnými principy fungování parlamentní demokracie, se směrem vývoje společnosti, s ekonomickou reformou, méně již se způsobem fungování parlamentu či sociálními dopady reformy.

Pravolevé dělení společnosti se i nadále jeví jako nosné a užitečné. Někteří západní politologové sice namítají, že tento př́stup je již zastaralý a postrádá smysl [Butler, Stokes 1974]. Zaznívají však i opačné názory, poukazující na schopnost průměrného voliče ohodnotit politické strany a potažmo i sebe $\mathrm{z}$ hlediska př́slušnosti $\mathrm{k}$ levici, pravici nebo středu. Tyto pojmy jsou běžné populaci srozumitelné a dobře predikují politickou orientaci voličů v západních zemích [Barnes 1971; Evans, Heath, Lalljee 1996]. Ke stejnému poznání dospěla i řada českých sociologů a institucí, které se problematice krystalizace politického spektra věnují systematicky od počátku jejího formování (STEM, SoÚ AV ČR). Data Střediska empirických výzkumů v této souvislosti např́íklad ukazují, že česká populace je téměř stoprocentně schopna umístit se v dimenzích levice-pravice, což už nelze tvrdit o jejím zakotvení na škále liberalismus-konzervatismus. Sebezařazení na škále levice-pravice představovalo zejména v období 1992-1995 nejrobustnější ukazatel, výborný prediktor politické orientace občanů. Je nutné podotknout, že přihlášení se k levici či pravici není pouhým souhrnem idejí, ale stále více koresponduje s postavením občanů ve společnosti, s její sociální strukturou.

Data výzkumů STEM zaznamenávají dlouhodobou stabilitu rozložení voličů na škále levice-pravice i poměrně ustálené ideologické zařazení nejvýznamnějších politických subjektů. Zdá se, že politická scéna je jak nalevo, tak napravo zřetelně konstituována, nicméně jejím významným atributem je absence typicky středové politické formace. Způsob zaplňování tohoto uprázdněného místa by mohl být jedním z klíčových momentů vývoje politické scény do budoucna.

\section{Hledání identity (1990-1992)}

Ze sociologických dat víme, že česká veřejnost se ke svému současnému politickému zakotvení dopracovala postupně. V této souvislosti lze mluvit o dvou zlomových bodech.

První z nich se váže $\mathrm{k}$ volbám v roce 1990, které přinesly jednoznačné vítězství nadstranického pravolevého Občanského fóra. Lze ho z hlediska politické orientace obyvatel charakterizovat jako hledání identity. Neexistence standardní politické scény, volání po širokém společenském konsensu, plebiscit o komunismu, to vše mělo za následek značné prolínání pravicových a levicových postojů a inklinaci občanů $\mathrm{k}$ široce vymezenému politickému středu. K centristické orientaci se hlásilo více než $50 \%$ občanů, což výrazně charakterizuje tehdejší dobu. Touha po změně, která sjednocovala zájmy jednotlivých skupin, nebyla plošně uspokojena. Odlišné představy o tempu a rozsahu přeměn vedly k rozpadu OF a následnému zpřehlednění politické scény.

Druhým významným momentem je přelom let 1991/1992, kdy dochází k redistribuci bývalých voličů OF mezi nové politické subjekty, ODS a OH. Neuspokojení z nedostatečného tempa společenských a politických změn se manifestovalo př́klonem k politické pravici. Pravicovost vyjadřovala zájem občanů na radikálních změnách a negativní vymezení vůči komunistickému režimu spíše než standardní politickou orientaci. Postupem času pojmy pravice a levice získávaly jinou náplň, což se projevilo celkovým posunem české veřejnosti $\mathrm{k}$ pravostředovým pozicím na politickém spektru. Na pozicích pravice zůstala ta část veřejnosti, která již z nové společenské situace profitovala, ostatní skupiny zaujaly rezervovanější postoj. I v tomto dynamickém období, které lze vnímat 
jako proces politického vyzrávání, si dospělá populace uchovala téměř stoprocetní schopnost zařadit se na pravo-levém kontinuu. Na rozdíl od značně abstraktního a zmateného chápání pojmů liberalismus a konzervatismus, reflektuje pravo-levé dělení skutečné politické smýšlení populace věrohodněji.

Po celé počáteční období transformace zůstává konstantní zařazení občanů na extrémních pozicích, krajních pólech politického spektra. Otevřeně se k jasně pravicovému či jasně levicovému proudu hlásí necelá šestina populace.

\section{Posun doleva se nekoná}

Kde se průměrný český volič $\mathrm{v}$ současnosti ideologicky nachází? Zjednodušeně řečeno blízko politickému středu, od něhož není daleko ani doleva, ani doprava. V praxi to znamená, že v nových volbách může většinově dát svůj hlas v podstatě kterékoli z velkých stran s výjimkou KSČM, př́ipadně SPR-RSČ.

STEM ve svých sociologických šetřeních sleduje sebezařazení občanů v dimenzích levice-pravice systematicky po celé období nejčastěji pomocí pětibodové verbalizované škály. Díky tomu lze na datech o sebezařazení respondentů doložit, že od minulých voleb nedošlo k žádnému dramatickému nárůstu počtu levicově orientovaných občanů.

Tabulka 1. Sebezařazení respondentů na škále levice-pravice 1991-1996 (v \%)

\begin{tabular}{|c|c|c|c|c|c|c|c|c|}
\hline & $6 / 90$ & $6 / 91$ & $6 / 92$ & $6 / 93$ & $6 / 94$ & $5 / 95$ & $12 / 95$ & $7 / 96$ \\
\hline Levice & 19 & 20 & 16 & 20 & 21 & 23 & 22 & 22 \\
\hline Střed & 51 & 43 & 33 & 40 & 41 & 41 & 41 & 41 \\
\hline Pravice & 30 & 37 & 51 & 40 & 38 & 36 & 37 & 37 \\
\hline
\end{tabular}

Zlomovými body změn politické orientace jsou volby v letech 1990 a 1992, kdy došlo $\mathrm{k}$ přehodnocení obsahu pravicovosti a středovosti. Více než polovina občanů se přihlásila ke středu (1990) či k pravici (1992). Zhruba v polovině roku 1994 nastává nové období, které trvá doposud. Myšlenka radikální reformy přestává být hybatelem změn, vyprchává ochota občanů k dalšímu „utahování opasků“. Do popředí vystupují sociální aspekty reformy, výrazněji se projevují odlišné zájmy jednotlivých skupin. Dochází k poklesu podílu pravicově orientovaných občanů, zatímco podíl levicově zaměřené populace zůstává neměnný. Výsledkem je nárůst počtu lidí hlásících se k politickému středu.

Česká společnost zůstává i po volbách společností pravého středu. Médii avizovaný obrat české veřejnosti směrem doleva sociologické výzkumy nepotvrzují.

\section{Nejvíce napravo v rámci Visegrádu}

Dlouhodobě stabilní rozložení občanů ČR na pravolevém kontinuu vynikne zvláště př́i porovnání s ostatními postkomunistickými zeměmi. STEM se již několik let podílí na mezinárodním srovnávacím výzkumu Občané a politické strany, jehož koordinátorem je Středoevropská univerzita v Budapešti. Na výzkumu se účastní kromě České republiky i Polsko a Mad’arsko. STEM realizuje rovněž výzkum na Slovensku. Projekt probíhá od roku 1992 a má podchytit odraz krystalizace politické scény středoevropských postkomunistických zemí ve veřejném mínění. 
Politické orientace jsou ve výzkumu sledovány řadou otázek, nejlépe je však vystihuje sebezařazení občanů na sedmistupňové škále levice-pravice (otázka: „V politice se často použivají pojmy levice, levý střed, pravý střed, pravice, apod. Podle toho, kam svými politickými názory patříte, se pokuste sám(a) zařadit na škálu od jedničky do sedmičky, kde jednička znamená jasnou levici a sedmička jasnou pravici.“).

Tabulka 2. Sebezařazení respondentů na sedmistupňové škále levice-pravice 1992-1996 (průměrné hodnoty; „1 = jasná levice, 7 = jasná pravice“)

\begin{tabular}{lccccc} 
& 1992 & 1993 & 1994 & 1995 & 1996 \\
\hline Česká republika & 4,67 & 4,40 & 4,41 & 4,29 & 4,45 \\
Slovensko & 4,06 & 4,04 & 4,21 & 4,35 & 4,36 \\
Mad'arsko & 3,79 & 3,82 & 3,80 & - & - \\
Polsko & 4,12 & 4,06 & 3,87 & - & - \\
\hline Pramen: & STEM, CEU Budapest, výzkumná série Občané a politické strany,
\end{tabular}

Výsledky ukazují, že česká populace se mezi zmíněnými čtyřmi postkomunistickými zeměmi dlouhodobě nachází nejvíce napravo, konkrétně se situuje na pozicích pravého středu. S výjimkou drobného výkyvu v roce 1995 (v téže době výzkumy zaznamenaly výrazný vzestup preferencí ČSSD) je toto zařazení velmi konzistentní a stabilní.

Zajímavý trend naznačuje srovnání české a slovenské populace. Ještě v dobách společného soužití byla politická orientace Čechů a Slováků značně odlišná. Česká populace se řadila na pravý střed, slovenská do středu. Slovenská veřejnost častěji promítala do pravolevého dělení své ekonomické šance, relativní deprivaci ve vztahu k České republice, pocit sociální slabosti, což ji situovalo blíže k levici. Po rozdělení federace jsme svědky relativního sbližování ideologických orientací obou populací v dimenzích škály levice-pravice. Na Slovensku dochází k předefinování obsahu pravicovosti. Ten se stává standardnější, více reflektuje tradiční hodnoty, religiozitu. Nicméně, dnes bychom na Slovensku těžko hledali programově pravicovou stranu, která by měla naději na výraznější úspěch ve volbách.

Data signalizují i sblížení mad'arské a polské populace. Mad’arská veřejnost v transformačním období 1992-1994 vykazovala stabilní pozici mírně nalevo od politického středu, což bylo v relaci s volebním vítězstvím socialistů. Poláci ve stejném období posunuli těžiště svých politických orientací zprava doleva. V politické rovině se tento posun záhy projevil vítězstvím sociální demokracie v parlamentních a A. Kvasniewského v prezidentských volbách.

\section{Politický střed a úspěch sociální demokracie}

Pravicově i levicově orientovaní voliči mají poměrně stabilní vazbu na konkrétní politické subjekty. Míra volebních fluktuací u občanů s pravicovou či levicovou orientací je omezená, proto představují pevné voličské zázemí politických stran. Př́ípadné přesuny těchto voličů neprobíhají např́íc politickým spektrem, ale mezi podobně orientovanými stranami. Typickým př́kladem je vzájemná směna voličů ODA a ODS. Centrističtí voliči naopak stabilního adresáta svých hlasů postrádají. Jejich volební chování je značně proměnlivé, méně je podmíněno ideologicky, více zohledňuje každodenní realitu. Významné zastoupení středových voličů najdeme s výjimkou KSČM u všech parlamentních stran, 
proto ani přesuny hlasů středově orientovaných voličů napříč politickým spektrem nejsou ničím výjimečným.

Z výše uvedených důvodů sehrává středový volič ve volbách velmi významnou, ne-li klíčovou roli. Je hlavním zdrojem volných, nezakotvených hlasů, o které mohou strany svést boj. Pokud se některému subjektu podaří ve volbách připoutat k sobě významnou část středových hlasů, může očekávat úspěch. V červnových volbách z této situace dokázala vytěžit především sociální demokracie.

Graf 1. Koho volili občané, hlásící se ke středu, levici a pravici
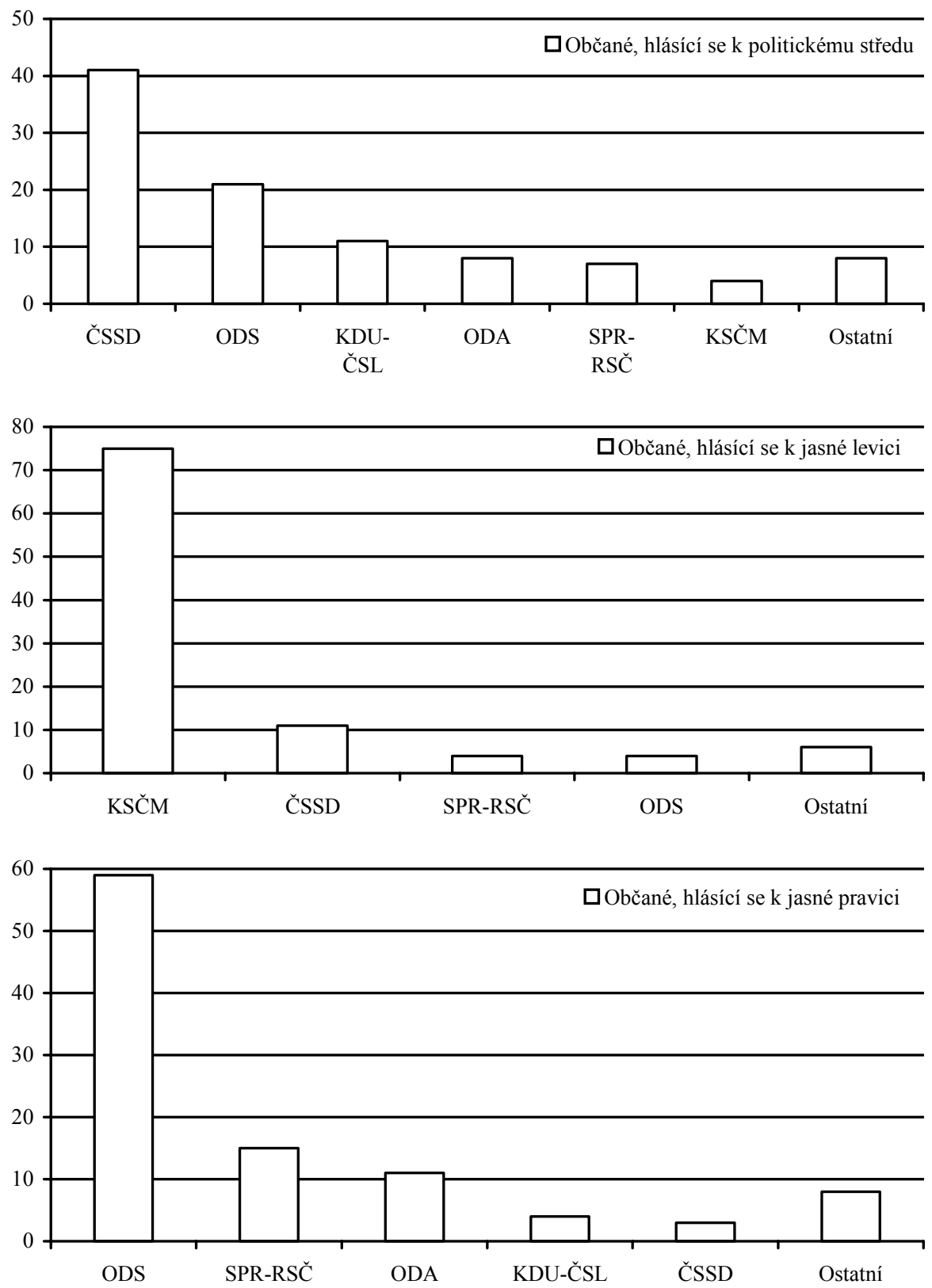
$\mathrm{Na}$ čem tedy stojí úspěch sociální demokracie, která dokázala odčerpat dvakrát více hlasů středových voličů, než ODS, a čtyřikrát více než KDU-ČSL. Především se ČSSD podařilo vytvořit image široce rozevřené strany, která nabízí každému něco, zároveň se však distancuje od krajních politických subjektů. V minulosti poměrně homogenní strana, opírající se především o levicově smýšlející občany středního a staršího věku, se přeměnila v demograficky i politicky heterogenní politickou sílu. Změnil se i př́stup veřejnosti k sociální demokracii. Ubylo negativních stanovisek k politice strany. Většina občanů pokládá sociální demokracii za stranu, která ne vždy přesně reprezentuje jejich názory a zájmy, avšak její politika se s představami voličů př́ímo nerozchází. Jinými slovy je všeobecně akceptovatelnou stranou, a právě tím neodrazuje nevyhraněného, umírněného středového voliče. Zmíněnou pozici sociální demokracie potvrzují data STEM.

Středisko empirických výzkumů opakovaně zjišt'ovalo míru identifikace občanů s jednotlivými politickými stranami. Respondenti posuzovali devět hlavních politických stran podle toho, jak vyjadřují jejich názory a zájmy (hodnocení na sedmistupňové škále od $-3=$ vždy velmi odporuje názorům, do $+3=$ vždy velmi vyjadřuje názory dotázaných). Jak ukazuje graf 2, ČSSD zaujímá pozici nejvíce príjatelné politické strany. Zajímavé je, že ještě v roce 1994 byla nejakceptovanější stranou ODA.

Graf 2. Do jaké míry strany vyjadřují názory a zájmy občanů

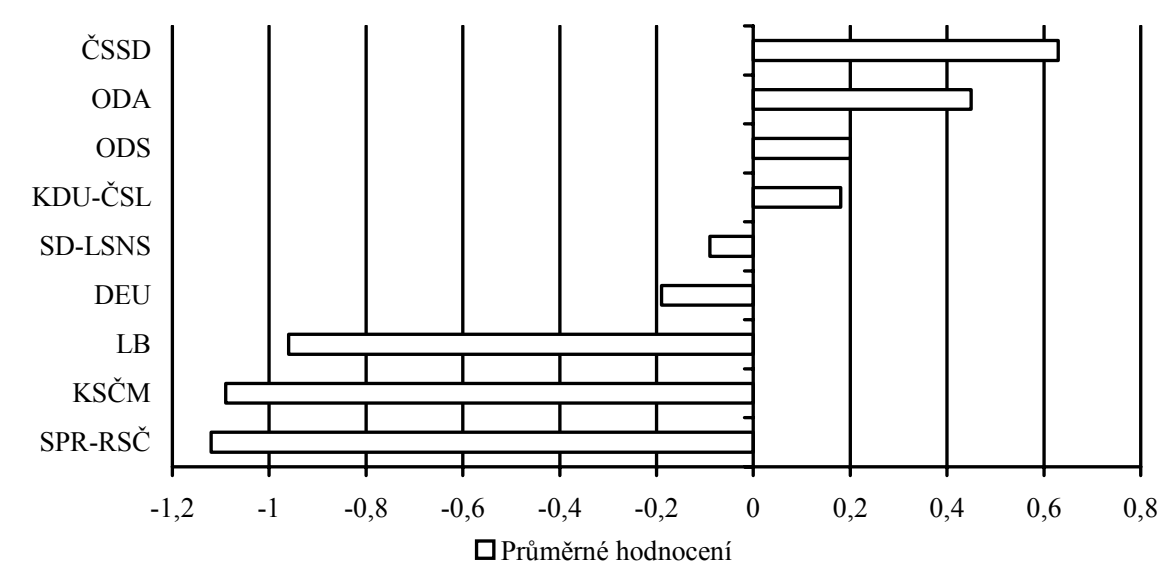

Připojená tabulka dokumentuje, že ČSSD sice disponuje méně početnou skupinu přesvědčených příznivců než volebně úspěšnější ODS, zároveň však ve srovnání s ostatními stranami vykazuje nejmenši skupinu krajních odpůrců.

ČSSD se k této pozici propracovávala postupně, o čemž svědčí dlouhodobý posun jejího voličského potenciálu zleva do středu. Počátkem roku 1993 se $52 \%$ př́znivců ČSSD řadilo k levici, nyní tak činí pouze $35 \%$. 
Tabulka 3. Podíl občanů ztotožněných s politikou strany $(+3 \mathrm{a}+2)$ a občanů, podle kterých politika strany výrazně odporuje jejich názorům a zájmům $(-3 \mathrm{a}-2)$

\begin{tabular}{lcc} 
Strana & \multicolumn{2}{c}{ podíl krajních hodnocení v \% } \\
$(+3 \mathrm{a}+2)$ & $(-3 \mathrm{a}-2)$ \\
\hline ODS & 34 & 27 \\
ČSSD & 32 & 13 \\
ODA & 28 & 14 \\
KDU-ČSL & 21 & 16 \\
KSČM & 14 & 52 \\
SPR-RSČ & 13 & 50 \\
LB & 12 & 44 \\
SD-LSNS & 10 & 14 \\
DEU & 10 & 16
\end{tabular}

Pramen: $\quad$ STEM, série Trendy 5/1996

Všeobecná přijatelnost, která se na první pohled jeví jako přednost, se může za jistých okolností změnit ve slabinu. Zatímco politicky vyhraněnější subjekty, včetně ODS, mají dlouhodobě velmi stabilní voličské jádro, s pevnou vazbou na stranu i její program, ČSSD v tomto významném ukazateli voličské stability značně zaostává. Středoví voliči představují konglomerát lidí odlišných zájmů, názorů a hodnot, občanů silně apolitických i politikou oslovovaných. Strany mohou takového voliče sice snadno získat, ale i velmi snadno ztratit. Středový volič je nejméně disciplinovaný, názorově nestálý, svůj hlas často neodevzdává z přesvědčení, ale např. z pocitu nerozhodnosti či nespokojenosti. Např́íklad velký zisk ČSSD na severní Moravě lze částečně přičíst právě tomuto jevu.

\section{Propad malých stran}

Voliči, kteří pro tzv. středové strany (OH, HSD-SMS, LSU) hlasovali v minulých volbách, v letošních volbách tento krok nezopakovali. Své hlasy raději rozdělili mezi silné parlamentní strany, přičemž největší část těchto hlasů spolkla Zemanova ČSSD (viz tabulku 4).

Tabulka 4. Koho volili bývalí voliči LSU, HSD-SMS a OH v letošních volbách ( $\mathrm{v} \%)$

\begin{tabular}{ccccccc}
$\check{C}$ SSD & ODS & SD-LSNS & ODA & SPR-RSČ & DŽJ & KDU-ČSL \\
\hline 39 & 20 & 9 & 7 & 7 & 6 & 4 \\
\hline
\end{tabular}

Pramen: $\quad$ STEM, výzkumná série Trendy, 6/1996

Byl to právě zisk téměř $40 \%$ hlasů těchto malých stran, který se významně podepsal na dobrém volebním výsledku ČSSD. Pokud se pokusíme zmíněná procenta hypoteticky přepočítat na jednotlivé hlasy, zjistíme, že reprezentují bezmála půl miliónu voličů. Co toto číslo v konečném volebním bilancování znamená, není nutno připomínat: fakt, že parlamentní většina unikla stranám vládní koalice o padesát tisíc hlasů, mluví sám za sebe. 


\section{Boj o politický střed}

Posuzujeme-li pozici politických subjektů na pravolevém kontininuu z hlediska sebezařazení jejich voličů, nacházíme na naší parlamentní scéně pouze dvě jasně zakotvené strany - zcela na levici KSČM a zřetelně napravo od středu se pohybující ODS. Zbylé čtyři strany sytí přehuštěný pravý či levý střed.

Dvě z nich, ČSSD a KDU-ČSL, se rozhodující mírou opírají právě o středového voliče. Sociální demokracie, kterou volby vynesly do pozice hegemona středu, se však nikdy za reprezentanta středu nepovažovala. Naopak Luxova strana tuto roli neodmítla, čímž přispěla ke zvěrohodnění středu. Voličské zázemí ODA se již výrazněji vychyluje $\mathrm{k}$ pravostředovým pozicím. Středový volič, hlasující pro alianci do jisté míry reprezentuje typ voliče, který straně nedává hlas z přesvědčení, ale např. proto, že jí chce pomoci dostat se do parlamentu. Tradičně nejméně čitelní jsou republikánští př́íznivci, v jejichž př́ipadě dochází ke kumulaci různých politických proudů. Nicméně, dlouhodobé srovnání chování voličů této strany naznačuje, že z původně folklórního fenoménu se pomalu začíná konstituovat politicky čitelnější voličské zázemí, které se sice nenápadně, ale přece jenom posouvá z naprostého zmatení k pravostředovým pozicím.

Podobné rozložení stran nastalo i v př́ípadě jejich umístění na pravolevém kontinuu běžnou populací a voliči daného subjektu. STEM se těsně po volbách dotázal respondentů, kde se na desetistupňové škále levice-pravice nacházejí současné parlamentní strany . Připojený graf 3 ukazuje, že zcela zřetelné politické zařazení mají opět pouze KSČM (jasná levice) a ODS (jasná pravice). Spíše jako pravicová než pravostředová strana se občanům jeví ODA, celkově ji však posouvají blíže ke KDU-ČSL než k ODS. Víceméně jako středové strany hodnotí občané KDU-ČSL a překvapivě i SPR-RSČ. Přesvědčivá se zdá být i levostředová pozice ČSSD.

Porovnáme-li rozřazení stran na škále levice-pravice podle obecné populace a podle voličů jednotlivých stran, výraznější diference se objeví v př́ípadě SPR-RSČ, KDU-ČSL a ODA. Př́iznivci všech tří subjektů situují svoji stranu zřetelněji napravo, než činí běžná populace. Naopak KSČM a ODS jsou politicky dobře čitelné, a tudíž neregistrujeme disproporce v jejich zařazení. Téměř jako středovou hodnotí svoji stranu voliči ČSSD. Lze předpokládat, že část voličů jí svůj hlas dala právě proto, že ji vnímala jako reprezentanta politického středu, nikoliv levice.

Zajímavé je i zjištění, že voliči jednotlivých politických stran sami sebe hodnotí na škále levice-pravice poněkud zdrženlivěji - více „ke středu“ než své strany. Patrně se tak projevuje tendence zařazovat se mezi „rozumné“, distancovat se od extremistů vlastní strany (platí pro KSČM, zároveň však i pro ODS). 
Graf 3. Složení voličů parlamentních stran podle levice-pravice (sebezařazení)

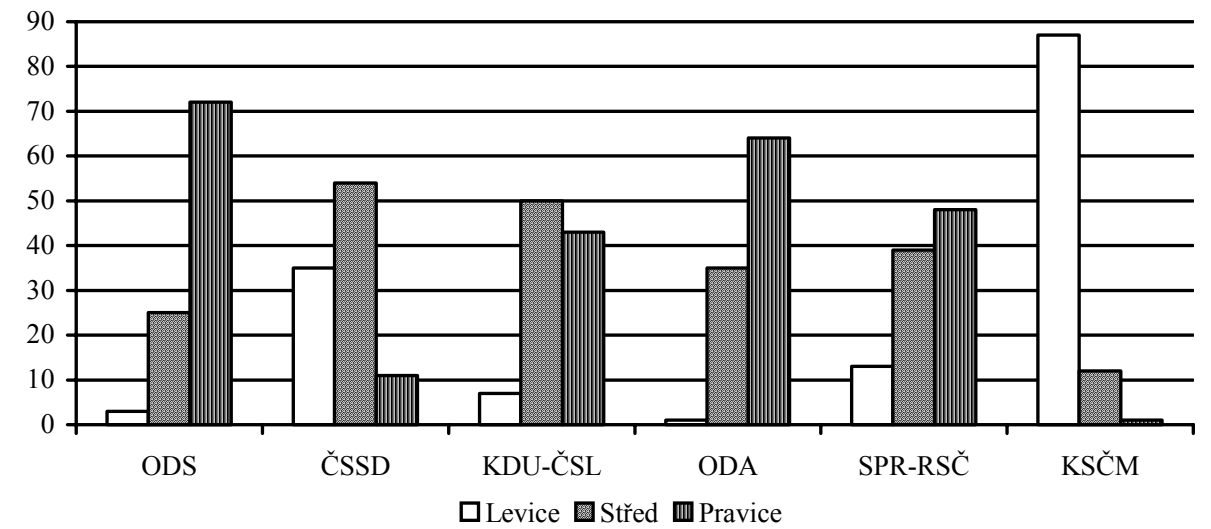

Pramen: $\quad$ STEM, Trendy 7/1996, N =1 559 respondentů

Graf 4. Zařazení stran na škále levice-pravice podle populace a voličů dané strany (průměr škály)

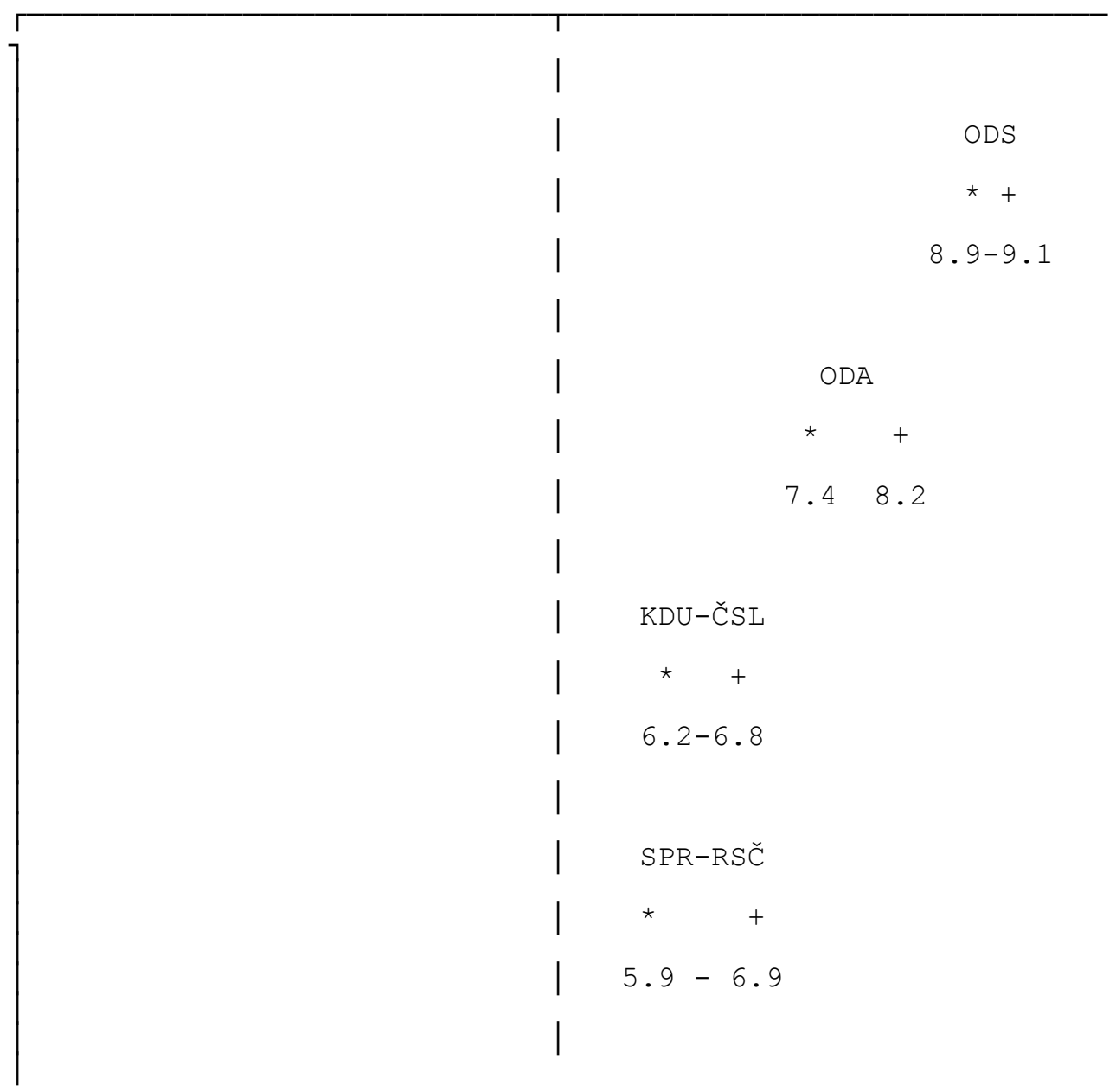




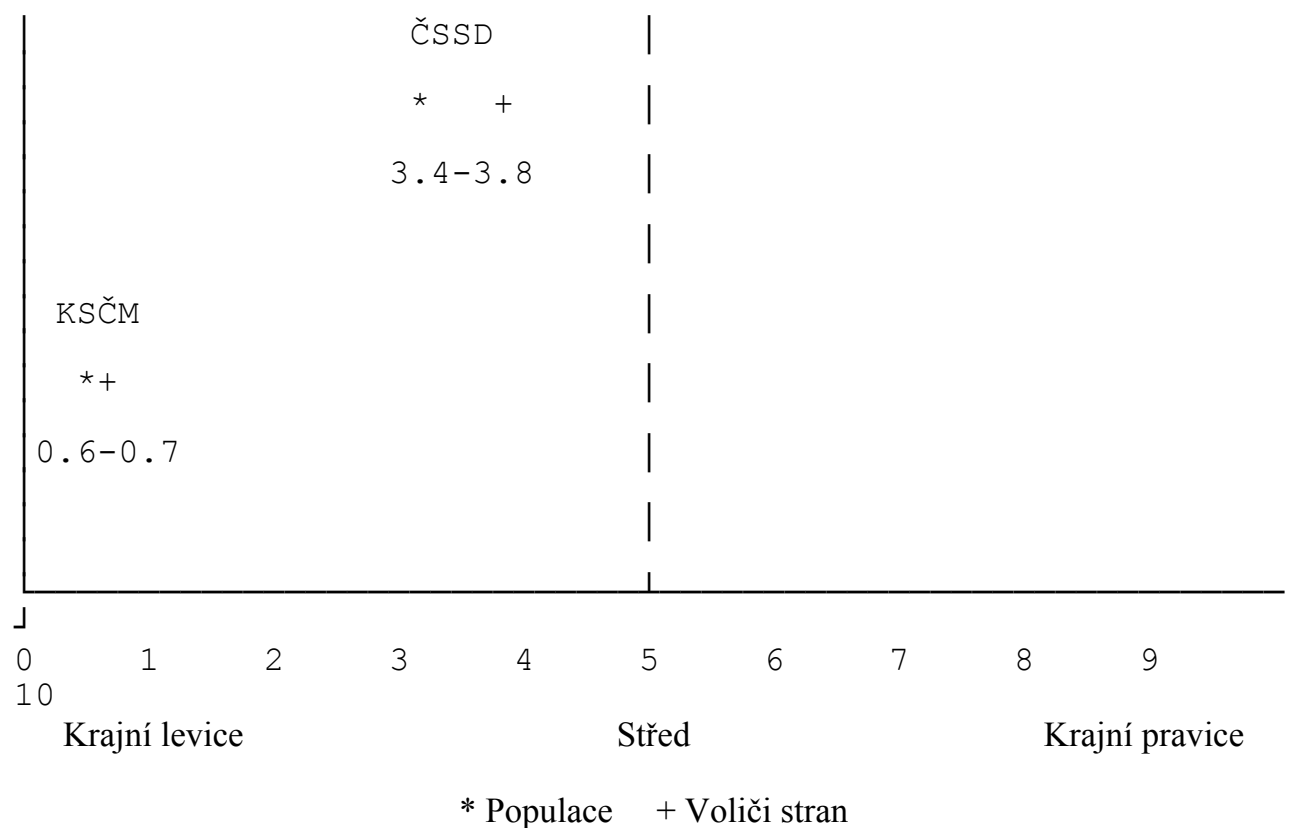

Pramen: STEM, Trendy 6/1996

\section{Základní charakteristiky středového voliče}

Sociologická data charakterizují středového voliče jako člověka politicky méně čitelného, který nemá rád extrémy a prímočará řešení. K politice prristupuje s jistou obezrretností, v $62 \%$ se o ni nezajímá. Své názory formuluje často dvojznačně, mlhavě. Za tzv. středovostí můžeme hledat i různorodost a protikladnost postojů. $Z$ těchto důvodů není vůbec snadné identifikovat středového voliče s konkrétním politickým proudem nebo subjektem. Strany s vyšším zastoupením středových voličů ztrácejí svoji jasnou orientaci, zatímco jasnost názorů voličů zbývajících stran se zvětšuje. Pokusme se závěrem alespoň částečně přiblížit politické směřování centristických voličů prostřednictvím několika vybraných postojů.

Středově orientovaní občané se od lidí s výraznějšśi ideologickou orientací (pravice, levice) liší v řadě základních stanovisek, at' již se týkají ekonomického uspořádání, politického systému, sociálních jistot či vnímání nerovností ve společnosti.

Ideální ekonomické uspořádání ČR vidí centrističtí občané v takovém ekonomickém modelu, který funguje na principu trhu, ale stát $\mathrm{v}$ něm hraje důležitou kontrolní funkci (43\%), nebo má př́ímo sociálně tržní podobu (33\%). Deetatizace je př́ípustná pouze $\mathrm{v}$ omezené míře. Přání mít $\mathrm{v}$ naší společnosti čistou ekonomiku volného trhu není u příznivců středu časté. Většinovou podporu má „čistý trh“ pouze mezi pravicí. Podobně jako levicově zaměření občané nepřipouštějí příznivci středu oslabení kontrolní role státu v ekonomice. Státně regulativní zásahy mají u obou skupin populace velmi vysokou váhu.

Návyk občanů na státní paternalismus z let minulých výrazně ovlivňuje očekávání a postoje nejen levicové, ale i středově orientované populace. Ta očekává, že stát bude i nadále za ni povinně řešit nepř́jemné věci, uchovávat rozsáhlý solidaristický systém produkující dokonalé zabezpečení pro rizikové situace. Neplatí to jen v oblasti sociální poli- 
tiky, ale také např́íklad ve školství a ve zdravotnictví. Je proto pochopitelné, že nejcitlivější body vládního prohlášení posuzují stoupenci středu spíše z pozic sociální demokracie než z pozic vlády: odmítají adresný systém vyplácení rodinných přídavků

(64 \%), zavedení školného na vysokých školách (75 \%) a naopak požadují ustavení institutu majetkových přiznání (75\%).

Rovněž vnímání nerovností ve společnosti je zatíženo minulostí. Rovnostářský př́ístup k majetku, skepse ke schopnostem jedince prosadit se v tržních podmínkách, předhazování odpovědnosti za osobní chudobu státu, a ne jedinci, to vše prribližuje stoupence politického středu názorům levice (viz tabulku 5).

Sociálně-demokratický prístup příznivců středu k ekonomice a státu, kritické vnímání nerovností, se v menší intenzitě promítají do politických postojů. Např́klad vztah středově orientovaných občanů k pravicové vládě není odmítavý. Podle $54 \%$ z nich pracoval Klausův kabinet v minulém období dobře a $44 \%$ si na postu premiéra nedokáže představit jiného politika než právě Václava Klause. Zemana by v čele kabinetu uvítalo jen $23 \%$. Optimisticky smýšlejí středoví voliči i o perspektivách nové vlády a parlamentu, od nichž očekávají, že budou pracovat lépe než jejich předchůdci. Pozitiva nad negativy převažují i v př́padě srovnání současného a předlistopadového režimu. V tomto ohledu se středoví voliči výrazně vzdalují postojům levicově zaměřené populace (viz tabulku 5).

Tabulka 5. Vybrané názory a postoje občanů podle jejich sebezařazení na škále levice pravice (sloupcové četnosti $v \%$ )

\begin{tabular}{lrrr} 
& levice & střed & pravice \\
\hline I. Postoje k ekonomice & & & \\
1. Preference typu ekonomiky & & & \\
$\quad$ Rízená ekonomika socialistického typu & 32 & 7 & 2 \\
$\quad$ Sociálně tržní ekonomika & 37 & 33 & 12 \\
$\quad$ Tržní ekonomika s kontrolní rolí státu & 26 & 43 & 37 \\
$\quad$ Tržní ekonomika s minimálními zásahy státu & 5 & 17 & 50 \\
2. Ekonomika by i nadále měla zůstat pod kontrolou státu & & \\
$\quad$ Určitě + spíše ano & 95 & 89 & 68 \\
$\quad$ Určitě + spíše ne & 5 & 11 & 32 \\
II. Politická participace a postoje k současnému režimu & & & \\
3. Zájem o politiku & & & \\
$\quad$ Velký + střední & 54 & 38 & 56 \\
$\quad$ Malý + žádný & 46 & 62 & 44 \\
4. Vztah $k$ volené straně & & & \\
$\quad$ Velmi + pomérně silný & 72 & 53 & 75 \\
$\quad$ spíše + velmi slabý & 28 & 47 & 25 \\
5. Postup v př́padě opakování červnových voleb & & & \\
$\quad$ Volil by stejnou stranu & 74 & 60 & 80 \\
$\quad$ Volil by jinou stranu & 15 & 19 & 15 \\
$\quad$ Nevolil by & 11 & 21 & 5 \\
6. Srovnání současného a minulého režimu & & & \\
$\quad$ Současný režim je lepší & 20 & 56 & 84 \\
$\quad$ Oba jsou stejné & 23 & 24 & 9
\end{tabular}


Současný režim je horší

$20 \quad 7$

7. Minulá koaliční vláda pracovala (1992-96)

Velmi + spíše dobře

$23-53-81$

Velmi + spíše špatně

$77 \quad 47$

19

III. Názory na vybrané sociální problémy

8. Př́lavky na děti by se měly vyplácet všem rodinám

Určitě + spíše ano

$69 \quad 64 \quad 46$

Určitě + spíše ne

$31 \quad 36 \quad 54$

9. Byty představují normální zboží, cenu má určovat trh Určitě + spíše ano

$\begin{array}{lll}10 & 19 & 33\end{array}$

Určitě + spíše ne

90

81

67

10. Na vysokých školách by mélo být zavedeno školné

Určitě + spíše ano

$\begin{array}{lll}15 & 25 & 47\end{array}$

Určitě + spíše ne 
Tabulka 5. Vybrané názory a postoje občanů podle jejich sebezařazení na škále levice pravice (sloupcové četnosti v \%) - pokračování

\begin{tabular}{lccc} 
& levice & střed & pravice \\
\hline IV. Postoje k nerovnostem ve společnosti & & \\
11. Současný režim zaručuje stejné šance pro všechny lidi & & \\
Určitě + spíše ano & 9 & 34 & 59 \\
Určitě + spíše ne & 91 & 66 & 41 \\
12. Za svoji chudobu si každý může především sám & & & \\
Určitě + spíše ano & 13 & 31 & 55 \\
Určitě + spíše ne & 87 & 69 & 45 \\
13. Vývoj rozdílů mezi lidmi byl v minulých šesti letech správný & & \\
Určitě + spíše ano & 13 & 43 & 72 \\
Určitě + spíše ne & 87 & 57 & 28 \\
\hline Pramen: STEM, série Trendy 7/96 (výroky 2-5, 7-10), Trendy 10/96 (výrok 1), \\
$\quad$ výzkum Vztahy ve společnosti 3/96 (výroky 6, 11-13).
\end{tabular}

V prŕípadě vypsání předčasných voleb dnes nelze spolehlivě předpovědět, jak se středový volič zachová. Pravděpodobné však je, že jeho volební účast v neplánovaných volbách by byla znatelně nižší, než tomu bylo v červnu ( 77 \% nepovažuje předčasné volby za nutné). O nestálosti a pro politické strany „rizikovosti““ středového voliče svědčí i další údaje. Pouze tři pětiny takto orientovaných občanů by $\mathrm{v}$ př́ípadě opakování červnových voleb odevzdaly hlas téže straně a pouze každý druhý občan hlásící se k politickému středu pocituje silnější vazbu k volené straně.

\section{Závěr}

Zásadní změnu politické orientace, ani posun občanů směrem doleva letošní volby nepřinesly. Pokud by skutečně mělo dojít $\mathrm{k}$ přesouvání voličủ $\mathrm{k}$ levici, znamenalo by to volání po změně režimu, o čemž sociologická data nevypovídají. Volby však přispěly k zpřehlednění politické scény, $\mathrm{k}$ jasnějšímu definování pozic politických stran i jejich voličů. Pozice pravice je dlouhodobě stabilní, nicméně došlo k vyčerpání rezervoáru volných hlasů. Podobně ustálené, ale limitované se jeví postavení levice. Možnost i dalšího posílení pravicových či levicových subjektů o jiné než středové voliče, tak zůstávají omezené. Proto se právě středový volič dnes stává tím, kdo může rozhodnout o charakteru vývoje do budoucna.

Zatímco politická pravice je spokojená se stavem společnosti, s jejím směřováním a jako jediná i s praktickým uplatňováním politiky, levice podrobuje formy realizace politiky silné a vytrvalé kritice. Stejně intenzívně zní i její nostalgické volání po předlistopadových poměrech, čímž se výrazně odlišuje od středu. Středoví voliči dnes zásadně podporují polistopadový vývoj, demokratický systém, jejich nespokojenost však vystupuje na povrch při hodnocení realizace forem politiky v dílčích oblastech (školství, zdravotnictví, bezpečnost apod.). Středový volič se $\mathrm{v}$ př́štích volbách proto pravděpodobně přikloní $\mathrm{k}$ tomu, kdo nebude zpochybňovat režim, ale nabídne srozumitelné řešení věcně definovaných politických témat „středního dosahu“.

PAVEL ŠIMONÍK vystudoval sociologii na Filozofické fakultě UK v Praze. Od roku 1992 pracuje jako analytik Střediska empirických výzkumi (STEM), kde se věnuje problematice politických stran a volebního chování. 


\section{Literatura}

Barnes, S. H. 1971. „Left, Right and the Italian Voter.“ Comparative Political Studies 4: 157-175.

Butler, D. E., D. Stokes 1974. Political Change in Britain. London: Macmillan.

Dvořáková, V., J. Kunc 1994. O přechodech k demokracii. Praha: Sociologicé nakladatelství.

Evans, G., A. Heath, M. Lalljee 1996. „Measuring left-right and libertarian-authoritarian values in the British electorate.“ The British Journal of Sociology 47: 93-112.

Hudeček, J. 1992. „Pokus o identifikaci stran na levo-pravém kontinuu.“ Sociologický časopis 28: 275-283.

Kapr, J., P. Kotlas 1993. „Výsledky voleb.“ In Volby zde a nyní. Praha: Egem.

Machonin, P. 1992. „Československé vztahy ve světle dat sociologických výzkumů.“ In Dnešní krize česko-slovenských vztahů, ed. F. Gál et al. Praha: Sociologické nakladatelství.

Matějů, P. et al. 1996. „Sociální třídy, postoje k nerovnostem a politické orientace - Vývoj v letech 1991-1995." Soubor textů a datová dokumentace k TK. Praha: SoÚ AV ČR.

Rezler, L. 1990. An attempt to identify background of political left and right continuum in Czechoslovakia. Praha: SoÚ ČSAV. 